\title{
Towards the semiotics of the observer
}

\author{
Marina Grishakova \\ Department of Comparative Literature, University of Tartu, \\ Ülikooli 17, 50090 Tartu, Estonia \\ e-mail: marina2@ut.ee
}

\begin{abstract}
The problem of the observer and point of view is examined within the broad semiological and cognitive perspective. Structuralist narratology made an attempt of a formal-linguistic classification of points of view to avoid anthropomorphic-visual connotations inherent in narratological terminology. The alternative opportunity would be the usage of terms-metaphors as theoretical models. From the point of view of the observer, the process of text generation evolves in the double space of perception/conception and interpretation. Instead of comparing different media in terms of the privileged metalanguage, it would be more fruitful to base the comparison upon their immanent cognitive characteristics.
\end{abstract}

The turn of the 20th century is traditionally seen as a period of the great modernist rupture. The break with classical models of vision occurs in different spheres of culture thanks to the invention of photography, cinema and experimentation in painting. Philosophers and art theorists relate the modernist turn to the crisis of the Cartesian observer and the system of the linear perspective the latter embodies. It is clear, for example, that, while speaking of the "denigration" of vision and the crisis of the "ocularcentrism", Martin Jay exploits a figurative meaning of "vision" (Jay 1993). In this case "vision" refers to the relationship of either the ideal subject and object of knowledge or the ideal beholder and the system of linear coordinates, i.e. to the epistemological or geometrical model based on the analytical observation. On the contrary, subjective vision and its bodily aspects are central within the new paradigms of knowledge that emerge in the late 19th - early 20th century. In his preface to Ruskin's Sesame and Lilies, M. Proust writes of "'the optics of minds' which prevents us 
from absorbing knowledge from others" (Shattuck 1964: 11). Thus the knowledge is seen as an outcome of subject's perceptual experience. As compared to the Cartesian rational, detached and disembodied subject, the modernist observer is actively involved in the interaction with the world and is seen as a part of reality, through which reality manifests itself. Therefore its status is ambiguous. It is, paradoxically, both an autonomous individual unity and a mobile perceptual field. Mobile strategies of observation are shaped by the permanent exchange of information between the observer and the observed. The whole "matrix of identity, predicated on the separation of the interiority of the observer from the exteriority of the object world" (McQuire 1998: 18) is called into question.

The observation is "unconscious" in the sense Derrida employs while speaking of "the fundamental unconsciousness of language (as rootedness within the language)" (Derrida 1997: 68). Likewise, the ordinary observer is immersed into the world, into the "sign medium" (Bakhtin-Voloshinov 1993: 17). He is "unconscious" of his own observation and involved in the process of signification as articulation of "différance", i.e. inscription of the "outside" into the "inside" and vice versa. M. Merleau-Ponty underscores an asymmetry and a split between spontaneous experience of the world and consciousness as "the absolute certainty of my existence for myself". As far as reflection goes back to the subject, "it ceases to remain part of our experience and offers, in place of an account, a reconstruction" (MerleauPonty 1981: ix). The notion of the "unconscious" is, of course, polysemantic. It might be understood either as a suppressed and inaccessible or as a semiactive and accessible part of experience. If Freud is inclined to use spatial metaphors and defines the "unconscious" as a locus, e.g. an ancient city or a dark chamber, William James in his "Principles of Psychology" introduces the notion of the "fringes" of attention in contradistinction to its "focus" to underscore mobility of the perceptive field. Likewise, the Lacanian definition highlights both elusiveness and the constitutive function of the unconscious as a gap between perception and consciousness, as "the place of the Other, in which the subject is constituted" (Lacan 1994: 45). The Lacanian unconscious is "not so much a position as an edge, the junction of division between subject and Other, a process interminably closing" (Heath 1981: 78). The observer is permanently constituted through the transformation of the border between the self and the Other.

The modernist turn leads to a new allocation of borders between art, science, technology, and everyday life. According to Mukaŕovsky, 
"any object and process, either natural or related to human activity, may become a bearer of the aesthetic function" (Mukaŕovsky 1984: 38). Scientific practices overlapping with art, e.g. optics, physiology, psychology, become involved in the sphere of art and endowed with aesthetic meanings. On the one hand, the conceptual frame of the modernist art is scientific. On the other hand, the nature of it is perceptual: it is deeply involved in what and how we see (Vitz, Glimcher 1984: 7). Therefore some critics are skeptical about the very notion of the modernist revolution. On J. Crary's opinion, the myth of modernist rupture "depends fundamentally on the binary model of realism versus experimentation. That is, the essential continuity of mimetic codes is a necessary condition for the affirmation of an avant-garde breakthrough". J. Crary believes that the site where the real change occurs is the observer (Crary 1992: 4-5). 19th century empiricist psychology discloses the role of perception in the constitution of the self and works out the philosophical grounds for sensory perception. J. Ryan argues that empiricist construction of subjectivity is a challenge for modernist writers and therefore a stimulus for new linguistic and literary practices (Ryan 1991: 9-12). The progress of physiological optics in the 19th century demonstrates that the world is to a certain extent "created" by the observer: such phenomena as colours or mirror reflections are devoid of autonomous physical existence and evoked through the observer's interaction with the external world. Every act of perception changes the reality (Gibson 1940: 40). Therefore, to continue the thought, every observer is a creator of an imaginary world and thus an "artist" in its own right. M. Merleau-Ponty highlights a creative aspect of attention: attention "is neither an association of images, nor the return to itself of thought already in control of its objects, but the active constitution of a new object which makes explicit and articulate what was until then presented as no more than an indeterminate horizon" (Merleau-Ponty 1981: 30). The question is how separate, partial observations are related to the continual knowledge of the world if such an integrated knowledge exists at all. The narratological problem of point of view in fiction makes part of a much broader problematics, which arises simultaneously in relativist physics, psychology, painting, cinema and literature of the modernist age: every description is related to a certain "self", the observer whose observation shapes the observed. Such notions as Walter Pater's "moment" or Joyce's "epiphany" refer to a creative perceptual act, "a particular intensity of perception in which the vanishing away is temporarily stayed", i.e. vision, which is akin to art (Ryan 1991: 28). 
Modernist art is highly self-reflexive and theoretical. Properties of the fictional space, the very condition of writing and relations between the author, narrator and character are modelled and explored by means of spatio-visual tropes (screen, mirror, window, lens, etc.) common for modernist fiction and theory. The notion of the observer is the focus where different trends of modernist thought meet. The history of this notion unveils tropological connotations inherent in contemporary semiotic and narratological terminology as well as its rootedness in the practice of art, philosophy and science.

Theory of the observer. Physical (Einstein) and linguistic (Whorf) relativity calls into question existence of a unique external reality and shows that observations of different observers, who use different frames of reference, result in mutually exclusive and irreconcilable, but equally valid pictures of the universe (Weltanschauungen) (see, e.g., Heynick 1983 on influence of Einstein upon Whorf). R. Jakobson points out some concordances between innovation in physics, developments of linguistics and ideas of artistic, literary and scientific avant-garde of the early 20th century. According to Einstein's own acknowledgement, his acquaintance with the "situational relativity" of the Swiss linguist Winteler inspired his future work. He found in Winteler "the indissoluble interconnection of the concepts relativity and invariance" (Jakobson 1985), which would become the cornerstones of relativity theory, modern linguistics and semiotics. The difference between invariance and variability overcomes the antinomy of the internal and external experience, the intelligible and the sensible: it "does not separate two domains from each other, it divides each of them within itself" (Derrida 1997: 64). Under the influence of Platonic tradition, the sign (as the unity of the idealized material form and sense) has been seen as an invariable inner copy of the variable external reality. As Derrida shows, this naturalizing-metaphysical understanding of sign is peculiar even to Saussure despite his notion of arbitrariness. In the Peircean triadic scheme, on the contrary, "the so-called "thing itself" is always already a representamen shielded from the simplicity of intuitive evidence. The representamen functions only by giving rise to an interpretant that itself becomes a sign and so on to infinity. The self-identity of the signified conceals itself unceasingly and is always on the move. The property of the repre-sentamen is to be itself and another, to be produced as a structure of reference to be separated from itself [...] The represented is always already a representamen" (Derrida 1997: 49-50). The sign is an 
articulation of the border between the "internal" and the "external". There is no "unbiased" immanent perceptual data: any perception is already "the meaning, the structure, the spontaneous arrangement of parts" (Merleau-Ponty 1981 (1945): 58). As Voloshinov-Bakhtin argues, quite in Peircean spirit, the sign does not belong to the internal, intuitively grasped sameness of consciousness: it is identified through correlation with other signs. The "sign material" is a medium, in which individual consciousnesses interact (Voloshinov 1993: 17). Bakhtin has recourse to the Husserlian notions of "intersubjectivity" and "appresentation" while speaking of the author and the character relationships (Bakhtin's manuscript of the 1920s "The author and the character in aesthetic activity"; Bakhtin 1979: 7-180). Totality of my own body is outside of my field of vision: I am on the border between the visible world of objects and the world of my inner experience. To translate myself from the language of inner experience into the language of external expression I need a transparent screen of the other person's reactions (Bakhtin 1979: 26-29). The other's role is that of the author: thanks to his "surplus" of vision in respect to myself I am placed into the world as a character among the other characters (Bakhtin 1979: 30). Likewise, thanks to my "surplus" of vision, I am in the author's position in respect to others. The other is given to me as an opaque body: it is my own inner experience, which turns him into a meaningful entity. My own self is always incomplete: the other is part of my experience (Bakhtin 1979: 22-24). Bakhtin's work belongs to the phenomenological-semiological tradition that concentrates on the problem of accessibility of subjective worlds. Both Husserl's phenomenological "Ego" and Uexküll's "Umwelt" denote the world of lived experience which is opaque for the outside observer and serves as a mediator for any perception and knowledge. The "Umwelt" is, paradoxically, both a closed autonomous system and a fragment of the "outside" reality. The sign "no longer signifies an object to a subject, but it signifies the reaction of a subject to an object" (Uexküll 1984: 192). Signification is seen as the articulation of the border between the observer and the observed. The participant observation means the observer must reconstruct a situation while observing its traces in the other observer's reaction and placing himself into the other observer's position (Husserl's "appresentation"). Merleau-Ponty highlights partial opacity of "private worlds" or the worlds of lived experience (Merleau-Ponty 1987: 10).

To summarize aforementioned approaches, human behaviour and mental acts are rooted in the subjective "worlds", i.e. biological, 
perceptual, linguistic cognitive spaces. Contemporary constructivist narratology focuses on the problem of subjective domains or "individual perspectives" in fiction (see Nünning 2001: 209). Yet, as we have seen, the borders of the subjective world are unstable, they are continually displaced and transgressed. In the fictional text, the function of the "observer" is variable in relation to the invariable functions of the narration/ enunciation.

The problematics of the "subjective worlds" may be traced in modernist literature as the latter takes the "perspectival" turn and focuses on the representation of other's consciousness and perceptual world. Protagonist's illness in V. Nabokov's short story "Signs and Symbols" might be understood in the light of the "Umwelten" theory as a case of expansion of the "subjective-self-world" up to the limits of the physical world. The young man is given a diagnosis of "referential mania" since everything that happens in the physical world seems to him "a veiled reference to his personality and existence": "Everything is a cipher and of everything he is the theme" (Nabokov 1995: 599). He feels himself absolutely transparent as if his inner movements would be observed and repeated in the external world. In the beginning of Proust's "Du côté de chez Swann" the narrator depicts the process of adaptation the body undergoes to accommodate the borders of the perceptual self to the room until the objects (clocks, mirrors, door-handles, etc.) become invisible since the space of the inhabitation coincides with inhabitant's inner space. VoloshinovBakhtin labelled modernism "relativist individualism", according to the forms of speech interference or the incorporation of the "alien word" into the author's speech (Voloshinov 1993: 31). As shown in Käte Hamburger's Logic of Literature, the representation of consciousness is a distinctive feature of narrative fiction in general and produces illusion of "another" reality. As modernist painting explores means of representation of illusory depth of pictorial space, likewise modernist literature focuses on exploration of the illusory depth of the represented consciousness. Individual worlds of consciousness are opaque, inaccessible for the outside observer: the omniscient narrator's direct intervention is rejected as an artificial device. Modernist literature plays up an insistent, almost paranoiac desire to know "what is inside". It either hands the narration over to the suspicious narrator who attempts to imagine and prognosticate other people's opinions and reactions or introduces multiple perspectives without a complete synthesis of auctorial omniscience. As if summarizing the modernist quest for the object of knowledge, M. Merleau-Ponty writes about a 
hypothetical "absolute object" which "will have to consist of an infinite number of different perspectives compressed into a strict coexistence, and to be presented as it were to a host of eyes all engaged in one concerted act of seeing" (Merleau-Ponty 1981: 70). Further developments of the nouveau roman are based, on the contrary, upon the viewpoint sliding along the surface and the world's optical resistance to the observer.

Problems of fictional form and point of view are closely scrutinized in literary theory of the turn of the century. Forms of the "alien" word and indirect speech in fiction or, otherwise, of the representation of other consciousness are the touchstones, where interests of major theorists meet and clash. D. Bordwell defines the two major trends in literary theory as the mimetic and the diegetic approach: "Henry James and Percy Lubbock proposed that the novel be analyzed as a theatrical or pictorial representation"; "Slavic theorists began to rethink fictional prose in linguistic terms". The latter tradition persists in continental structuralism and semiotics (Foreword in: Branigan 1984: XI). However, the two trends have never been fully detached due, first, to insufficiency of only spatio-visual or only linguistic analysis of the work of fiction and, second, to the tropological (iconic) constituent of literary terminology. It is true that the Formalist theory is based upon the linguistic criteria: the artistic speech is seen as a function of the ordinary language, a "creative deformation" of the latter. A new work of art is first and foremost a new form (Shklovsky 1929: 31). However, to motivate the "content" the Formalists resort to the mimetic criterion: the "content" is defined through the generic choice (ustanovka) and through the transposition of non-literary generic features (e.g. these of rhetoric or documentary genres, of the anecdote, diary, letter, oral speech, etc.) into the literary system. Thus, in his article "How Gogol's Overcoat is made", B. Eikhenbaum analyses Gogol's skaz as a system of "mimetic-articulational gestures", i.e. as a transfer of oral speech forms into the written text (Eikhenbaum 1986: 46). Bakhtin approaches the "alien speech" as a site of intersubjectivity and dialogism. On his opinion, the word is originally dialogical or "double-voiced" as a reaction, a response to the other's word or reflection of it: the language lives within the dialogue (Bakhtin 1994: 396-399). V. Vinogradov occupies a middle position between the formal-linguistic and phenomenological approach. Being himself a linguist, he defends poetics from the formalist linguistic totalitarianism and criticizes Eikhenbaum's formal analysis of Gogol's skaz. He regards text as the integral "whole", despite involvement of 
its elements in different (linguistic, cognitive, cultural, historical, etc.) contexts. Analysis proceeds from the whole to the parts (Vinogradov 1980: 94). A formalist-structuralist tinge of Vinogradov's work is counterweighted by the principles of continuity, dynamics and interference of levels of the multidimensional textual whole. Instead of the linguistic grid, to which the text is subordinated in structuralist analyses, Vinogradov's model involves mobile planes of the synchronic/diachronic, socio-cultural/individual, object (objektnye) / subject (subjektnye) forms of speech. For Vinogradov, the "alien speech" is a constructive element of textual architectonics, i.e. its composition. While highly appraising Bakhtin's analysis of the "alien speech" in fiction, Vinogradov criticized his notions of "polyphony" and "dialogism" as applied to the relations between the author/ the narrator/ the character ("plurality of equal consciousnesses with their own worlds" - Bakhtin 1994: 14). On Vinogradov's opinion, neither the character nor the narrator is ever equal to the author or able to enter the full-fledged "dialogue" with the latter: the forms of the "alien speech" are manifestations of auctorial "masks", "agents" or "actors", which all belong to the author's consciousness. The discussion on intersubjectivity vs. intertextuality of the 1960-70s takes up the old argument between linguists and phenomenologists/ semiologists. On J. Lyons' opinion, intertextuality is inevitably to be supplemented by the extratextual information:

Such writers as Kristeva (1969) and Barthes (1970) have insisted that what is commonly referred to as intersubjectivity should be more properly described as intertextuality, in that the shared knowledge that is applied to the interpretation of text is itself the product of other texts /.../. Up to a point this is true; and especially in so far as literary texts are concerned. But not all of the intersubjective knowledge that is exploited in the interpretation of texts derives from what has been previously mentioned [...] (Lyons 1977: 672-673; Lyons refers to Kristeva's "Semiotikè" and Barthes" "S/Z").

For Vinogradov, the narrator is only a metaphor, a manifestation of the relationship between the auctorial image and the fictional world (see A. Chudakov's commentary and excerpts from Vinogradov published and unpublished works in: Vinogradov 1980: 302-303, 327). “...the author's artistic world is presented not as objectively reproduced in the verbal medium ("v slove"), but as peculiarly mirrored in the plane of narrator's subjective perception or even transfigured within a series of strange mirror reflections" (Vinogradov 1980: 42). Therefore the narrator as well as the character of skaz-forms is a unique blending of subjectivity and objectivity. Both are only to a 
certain degree differentiated or personified, serving at the same time as "shadows" or manifestations of the higher-order subjectivity (Vinogradov 1980: 328).

The Anglo-American narratological tradition descending from $\mathrm{H}$. James exploits visual metaphors (focus, reflector) to describe indirect presentation through the character's consciousness. Early AngloAmerican approaches are summarized in Norman Friedman's article (Friedman 1955). Bakhtin highlighted phenomenological and semiological aspects of the "alien" speech. Vinogradov focused on the compositional as well as cultural-linguistic value of the different speech forms. In the early Anglo-American narratological tradition, the centre of gravity shifts to the accessibility of fictional knowledge. Thus, on the one side, narratology concentrates on the cognitive and linguistic aspects of the author/ narrator/ character relationships. On the other side, a strong realist bias leads to naturalization (anthropomorphization) of the narrative instances in accordance to the naïve empathic reading. The narrative text has a double status of a written text and a fictional world. Thus, literary scholars sometimes make efforts to reconstruct missing information or to find the source of narrator's knowledge on commonsense grounds, i.e. to take the author's responsibilities and to expand or supplement the text. Visual connotations of narratological metaphors lead to the equating of the "point of view" or "focus" with physical vision. H. James" prefaces, for example his famous description of the "house of fiction", are rich in visual semantics and may provoke anthropomorphization of the narrative agents. The description is, of course, a complex metaphor. There is an apt analysis of it in (Jahn 1996). M. Jahn demonstrates that H. James" "window" is above all "the viewer's "consciousness" and its construction of reality" (Jahn 1996: 252). He argues that Jamesian poetics and structuralist narratology are anthitetical as "visioncentered poetics" and "textocentered" narratology (Jahn 1996: 262). However, as we have already seen, metaphor as a cognitive model links the "ocularcentric" and "logocentric" poles of narratology and erases their antagonism.

Contemporary Foucault-influenced critics, who practice the naturalistic approach to the literary text and ignore the tropological divergence inherent in the literary terms, blame the realist author for the police control he exercises over the characters by means of "panoptical vision". As Dorrit Cohn justly observes, Foucault's power relations exist only between acting subjects or "ontological equals". Their application to the narrative instances is unmotivated. Further she 
points out that panoptical vision is a means of external manipulation: "The guardian /.../ can only perceive his subjects' manifest behavior, which he can punish or reward" (Cohn 1995: 9, 13). However, external manipulation or physical coercion is for Foucault part of the broader process of "normalization": power structures not only control the body, but are interiorized in the subject's mind as well. Cohn's attempt to refute the notion of auctorial/ narratorial "omniscience" to show, with the aid of Genette's theory, that narration is, on the contrary, a process of "restriction" of omniscience, is not fully convincing. Genette proceeds from the idea of "complete information" (Cohn 1995:12), i.e. diegetic information or the knowledge of the fictional world as the author's/ narrator's property, which is consecutively restricted through the acts of focalization, i.e. fictional characters' perception. The scheme indeed resembles the Foucauldian picture of control, the more so that novelists themselves often playfully underscore the character's dependence on the auctorial will. If, however, to place the text into a broader author's/ reader's cognitive perspective, the fictional world as an effect of "a revelatory vision that provides imagined beings with an imagined inner life" (Cohn 1995: 13) would be a means of "appresentation", participant observation or constitution of the Other as part of the self, which should lead to the extension of the cognitive perspective and the growth of knowledge.

To avoid visual and hence anthropomorphic connotations structuralist narratology worked out several formal typologies of narrative instances. Chatman emphasizes that the narrator is not really contemplating the scene he is reporting: the narrator is "a reporter, not an "observer" of the story world in the sense of literally witnessing it" (Chatman 1990: 142). According to M. Bal, the chief originality of Genette's work consists in separating the categories of narrative instance and point of view (Bal 1991: 75). The separation is already apparent in H. James' prefaces and works by German and Russian theorists. However, the point of view and the narrative instance, being separated, are also mutually dependent: the "alien word" is "alien" being contrasted with the other's speech. It is a phenomenon denoted as speech interference (Bakhtin), alternation of object (objektnye) and subject (subjektnye) forms of speech (Vinogradov), intersection of speaker's and hearer's speech spheres or "interlinguistic" bilingualism (Uspensky). Narration and point of view are inseparable. Genette brings them apart as two independent categories of mood (distance, focalization, perspective) and voice (the narrating instance, the narrative level and time of narration). 
In Genette's description, the whole "package" of narrative information is limited or shared through the introduction of narrative instances according to the narrative levels and narrator's relationship to the story. Information is channelled through zero-, internal or external focalization (Genette 1980: 189). The linguistic term "mood" is employed to define a "degree of affirmation" correspondent to each narrative instance as compared to the indicative mood of the "full" story. The term denotes an amount of information available to the narrator or the character through the acts of perception. Genette retains visual and spatial metaphors, despite his will to stick to a stricter linguistic terminology, and links focalization to visual perception. The smaller the distance, the broader the perspective, the more information available: "as the view I have of a picture depends for precision on the distance separating me from it, and for breadth on my position with respect to whatever partial observation is more or less blocking it" (Genette 1980: 162). Thus, while using the term "focalization" "to avoid visual connotations", Genette loosely employs visual and spatial connotations to explain the term. He also does not make a clear distinction between the "point of view" (the observer), "field of vision" (the observed) and "focus". If internal focalization is equal to the description of what the character sees (Genette 1980: 192), a difference between the internal and external focalization is erased (on these and other inconsistencies see: Bal 1991: 83-86; Phelan 2001: 54). Further Genette digresses from his intention to equate focalization with the observed and defines it either as an act of physical perception or as emotional attitude. If focalization is restricted to physical perception (first and foremost visual perception, but also auditory, tactile, etc.) its value is purely thematical. Genette's ultimate aim is to separate the "information" from the "interpretation" (Genette 1980: 197). Yet perception is already cognition and thus shaped by observer's subjectivity. If focalization embraces cognition (as in RimmonKenan 1986, who follows in Uspensky's footsteps), the distinction between the point of view and focalization is blurred: there is no need to duplicate the term. What matters is a difference between different points of view as centers of subjectivity organizing fictional space, not a difference between the narration and focalization. In that case there is no non-focalized narrative, i.e. a narrative not tied by the point of view or alternation of point of view. The alternation is itself the constitutive basis of the compositional architectonics of the fictional text, which is not identical to Genette's hierarchy of narrative levels. A description of the forms of relationship between the different points 
of view, or otherwise "structures of composition" (Uspensky) or "narrative patterns", are more important than the problem of holding focalization and narration apart. Sometimes the narrator's point of view dominates over the "alien speech" embedded into his speech, or, on the contrary, he lets the alien point of view dominate while using the other's word and adopting the role of the reporter or transmitter. Sometimes the two voices merge, e.g. in the narrated monologue, in the psycho-narration or when the "omniscient" author/ narrator performs the editing function (Friedman's "editorial omniscience"). Uspensky uses Friedmann's notion to explain bilingualism in "War and Peace" as edited or constructed by the author (the bad French translated into the bad Russian, the auctorial speech translated into the character's idiom or vice versa). The first-person narration with internal focalization (Defoe, Proust, Camus), where the narrator is supposed to say "not more than any of the characters knows", involves a distance (temporal, spatial, psychological, etc.) between the narrator and the character. The narration vacillates between zero- and internal focalization: it contains the signs of omniscience and at the same time includes ellipses and prolipses, i.e. withholding of information unmotivated from the viewpoint of omniscient narrator. Since Genette closely scrutinizes Proust's narration, the latter proves to be an exception of every rule Genette sets. Therefore new categories (polymodality, pseudodiegesis) are introduced. However, as it seems, the narrative peculiarities Genette discovers in Proust are rather usual in fiction, yet the categories of mood and voice are not flexible enough to describe them. Genette's system 'does not take account of all the modes of the observer's presence [...], nor does it explain the constituting of partial cognitive spaces, characterized by the presence [...] of two cognitive subjects in communication with each other" (Greimas, Courtés 1982: 121).

Uspensky's work is based upon the analogy between the literary and pictorial forms: the point of view is seen as a mobile centre shaping the "natural" architectonics of the work of fiction. Uspensky was probably first to describe the function of the deictic or expressed centre of subjectivity in fiction (his "Poetics of Composition", 1970) before R. Harweg (1975) and F. K. Stanzel (1977), whom M. Fludernik names as A. Banfield's precursors (cf. Banfield's "empty centre"). Uspensky shows how a single word is sufficient to turn the external point of view into the internal one or vice versa ("heterodiegetic" vs. "homodiegetic" in Genette's terminology). According to F. K. Stanzel, it is the omniscient narrator, who is provisionally localized or 
"figuralized" in the fictional space. As M. Fludernik argues, it is the reader who "takes an internal position on events (as if through a witness)" (Fludernik 1998: 390-391). Uspensky is not quite consistent in his classification of such centres of subjectivity: he either characterizes them as positions provisionally assumed by the author/ narrator or calls them "operators" (Uspensky 1970: 115). M. Bal (1991) also follows in Uspensky's footsteps, while admitting, that "focalization" is to be understood in the broad sense as cognitive "orientation". J. Fontanille (1989) overtly refers to Uspensky in his work, where the semiotic theory and narratological developments are combined to bring the "point of view" back to its cognitive function. He criticizes Genette's "focalization" as a pure technical or rhetoric device. Fontanille proceeds from Greimas' distinction between the cognitive, pragmatic and thymic agents delegated by the enunciator to control operations of the enunciatee (the reader, the hearer). The enunciation is then both a space of realization of the semionarrative or "mise-endiscourse" structures and an intersubjective space of communication between the enunciator and the enunciatee (Fontanille 1989: 6). The observer as the enunciator's agent is, according to Greimas, a cognitive subject "to exercise the receptive and $[\ldots]$ interpretative doing" (Greimas\& Courtés 1982: 217). Fontanille introduces the notion of the subjective space of observation, which is oriented and stratified in respect to the observer: the observer is thus a pure actant, a "conceptual focus" or a "centre of orientation", not necessarily corresponding to a person (Fontanille 1989: 7). While avoiding anthropomorphic connotations, Fontanille retains the cognitive aspect of vision. He suggests the following semiotic typology of the observers in visual and verbal arts, where the first term denotes the pure cognitive actant and the second the same actant in the pragmatic dimension, i.e. an actant responsible for the material realization of the enunciation or a performer: (1) focalizer/ narrator: a (non-localized and nonpersonified) cognitive filter; (2) spectator/ relator: endowed by minimal spatiotemporal localization, a deictic centre or a centre of subjectivity; (3) assistant/ witness (e.g., the ancient chorus): a personified non-participant; (4) assistant-participant/ witness-participant (e.g., a detective in crime fiction): the thematized observer; (5) assistantprotagonist/ witness-protagonist. Thus, semiology takes the visual metaphor of the observer (or the point of view) at its face value to employ it as a theoretical model (in M. Black's terminology) to draw all possible inferences and to explore parallels between observation and conceptualization. The same process is going on in cognitive 
linguistics that works with the figure/ ground, scope/ focus and other spatio-visual modelling notions. R. Langacker outlines a parallelism between perception and conception and equates the "observer" with a speaker, "whose "observational" experience resides in apprehending the meaning of linguistic expression" (Langacker 2000: 204). He underscores that certain aspects of visual perception constitute conceptual capacity. The minimal meaning-generative unit consists of two observers or interlocutors, who "accommodate their divergent perspectives, and negotiate the adaptation of conventional patterns to the idiosyncratic complexity of the immediate context" (ibid, 389).

Fontanille's typology of observers restores connections between the narration and point of view and separates them along the new lines: the "observer" is a metaphor for the cognitive function of narration and thus unifies the mimetic and the diegetic aspects of the narrative text.

As for Fontanille's scheme of the cognitive stratification of space, it is mostly based on spatial criteria. There are a lot of studies based on other spatial parameters as well: a choice depends on the specific objects and tasks of a research. In the case of fiction one should take into consideration semantic stratification of the observational space or "the clustering of intonation units into larger segments that express larger coherences of information" (Chafe 1994: 29), i.e. discourse topics and figures. As Chafe argues, fictional representation takes place in double perspective: it involves a dissociation of the represented or extroverted consciousness and the representing or introverted consciousness, which deals with representation through the processes of remembering and imagining of the data present in the extroverted consciousness. F. Kermode describes the double process of the narrative production as "a dialogue between story and interpretation" (Kermode 1980: 86). Therefore it is reasonable to speak of the double space of perception/ conception and interpretation. The work of interpretation is part of perception: it occurs through perspectivization, i.e. interaction of cognitive spaces ("frames of reference" in B. Hrushovsky's terms; see also Nünnig 2001). Contemporary linguists use the notion of perspective as a synonym for represented consciousness (Chafe 1994: 268-269; Sanders, Redeker 1996). It would be more exact to define perspective as a relationship of the embedding consciousness' (character's/ narrator's/ author's/ reader's) "surplus" of vision to the embedded consciousness. The term "perspective", in contrast to the Bakhtinian "dialogue", underscores directionality of the relationship: the "surplus" of vision is a background, against 
which points of view are determined as articulations of the textual/ extratextual, diegetic/ extradiegetic, fictional inside/ outside spaces.

Perspectivization could mean either a simple juxtaposition of points of view or their figurative correlation. Directionality and the interpretative relationship are characteristic of trope or figure (see an overview in Grishakova 2001). The meaning of trope is open and context-dependent: "The knowledge, corresponding to the character of the metaphorical expression, resembles the "direction" contained in the characters of indexicals like "I". Both instances of characteristic information endow their respective types with a power or potential for further, future interpretation lacked by the characters of expressions (types) that are context-independent". By that means, J. Stern argues, metaphors are never linguistic types, "but interpretations (or uses) of expression tokens in contexts" (Stern 2000: 269, 179). The interpretative relationship between "figure" and "context" is established through a "split reference" (R. Jakobson's term; see Ricoeur 1997: 224): a figurative expression denotes an object or phenomenon of the fictional world and at the same time refers to a broader figurative meaning of it. Ricoeur employs the term "configurational act" to denote the cognitive operation of mental synthesis or "grasping together" (prendreensemble) of the heterogeneous elements (Ricoeur 1990, 1: 66). He argues that a configurative act carries out mediation between the pretextual cognitive schemata and the narrative. We use the term "figure" (configuration or pattern) to denote the linkage of textual and extratextual elements as a unique and open semantic form. According to J. Lotman, trope is an equivalence established between a series of discrete units (signs) and continual semantic fields (images, dreams, memory, cultural symbols, social behaviour, gestures and actions, ritual practices, etc.). It is always based on approximation and displacement since discrete and continual languages are mutually intranslatable (Lotman 1981: 10). Hence the figurative pattern is not a sum of clearly delimited semantic units, but a vague entity with fuzzy boundaries. Meanings of the configured concepts are apprehended against the background of the vague semantic fields. Another important characteristic of trope is its experiential or perceptual basis. Any metaphor, even a dead one, encloses a trace of a perceptual act, which could be activated through the further figurative interplays to shape further perceptions: “...the particular content of a metaphor can be said to constitute an interpretation of reality in terms of mental icons that literally allows us to see what is being talked about" (Danesi 1995: 266). Thus, metaphor, in its broad sense as figurative speech in 
general, has aroused the interest of many modern philosophers and scientists starting from Nietzsche thanks to its ability to link the realms of "pre-cultural" and cultural experience, to introduce primary perceptions into the sphere of culture. The majority of Lakoff's examples (Lakoff\&Johnson 1981) are anthropocentric metaphors, where human primary experiences with physical objects are projected upon the domain of mental and spiritual processes. G. Lakoff has shown that spatial and visual metaphors belong to the core of human experience and are primarily connected with basic orientations in physical space. In certain periods visual and spatial metaphors are especially active as filters of cultural perceptions. They fulfil the modelling function in scientific and artistic discourses and shape a new cognitive experience of the modernist age.

The field of observation in interart studies. Interart studies mostly concentrate on the problem of translation of visual languages into the verbal language and vice versa (ekphrasis, the verbal transposition of montage, the camera eye, close-up etc.). However, as it is well-known, "cinematographic" devices such as montage or close-up existed in literature before the cinema was invented. S. Eisenstein borrowed the idea of montage from "Madame Bovary". "Sergei Eisenstein's essay, "Dickens, Griffith, and the Film Today", demonstrates how Griffith found in Dickens hints for almost every one of his major innovations" (Bluestone 1971:2). Often it is difficult to distinguish between the conscious verbal transposition of cinematographic devices and the visual transposition of literary devices, on the one side, and "the impressions left by thought structures" (Mitry 2000: 17) in both visual and verbal media, on the other side. In Mitry's opinion, there exist mental structures or operations underlying verbal and visual expression. However, the ways they are translated into the verbal and visual media are different.

"For in literature we see tracking shots, pans, close-ups, and dissolves when we observe quite simply the expressions of these same forms of thought, the same rhythmic associations and the same descriptive sequences - except that the means are different, means which try to give, in a roundabout fashion, what the cinema achieves directly" (Mitry 2000: 18).

Therefore the discovery of pre-cinematic expression "in the works of Virgil, Homer, Livy, Racine, Victor Hugo, Byron" etc. is devoid of interest not only from the film point of view but from the literary point of view as well: "the basic characteristics of film expression derive 
from the thought processes to which language has accustomed us" (ibid, 17). The scholar is taking a certain risk while speaking of the impact of the cinema on literature even during the cinematic era unless there is a conscious rendering of the visual elements in the verbal media, for example in works of those writers who were actively involved in cinematography and screen adaptation. However, even in this case it is sometimes difficult to separate "cine-mimetic" and literary devices. Acording to A. Appel's testimony, V. Nabokov's "Camera Obscura" was written as a film imitation (Appel 1974: 258). However, a number of novel's devices classified by G. Moses (Moses 1995: 74) as cinematic (e.g. "the articulation of settings by means of camera position", "eyeline-shots") are identical to the usual narrative techniques (description, alteration of point of view, etc.).

The montage principle in literature is the classical locus of the interart studies (e.g. Timenchik 1989, Ivanov 1988). There is also a number of less explored or even unnoticed devices of transposition, such as the reproduction of the filmic mechanism of connotation. A film pattern may be organized by a recurrent visual or an acoustic detail whose meaning "extends over the denotative meaning, but without contradicting or ignoring it" (Metz 1991: 110), for example the pince-nez of doctor Smirnov who is thrown over the board in Eisenstein's "Battleship Potemkin" or murderer's whistling in Lang's "M". The detail is neither purely conventional nor purely symbolic. The pince-nez means simultaneously the absence of doctor Smirnov and the defeat of the ruling class. According to C. Metz, a value of such detail is increased by the additional meaning it acquires in film, although what the detail symbolizes is a situation, a part of which it is:

"Thus the partial arbitrariness; thus the absence of total arbitrariness" (ibid). Such are, for instance, the knife and whistling in Lang's "M". The murderer whistles a melody from "Peer Gynt". The knife is used to peel an orange or to open a letter: the audience could only guess whether the knife has another function as well. The sinister "sardinnica" (the sardine-can) in Belyi's "St.-Petersburg" (see interesting remarks upon the linkage between the explosion, eating and sneezing topics in: Tsivian 1991: 217-218), light refractions in Olesha (Michalski 2000: 224-225), the yellow post in Nabokov's "Despair", whistling and the poster in "Laughter in the Dark" ("Camera Obscura") are other examples of the index details.

However, even in the case of intermedial transposition there occurs a re-creation and a new formulation of a visual message by literary means, i.e. its translation into literary poetics. Thus, cinematic 
"Aesthetik des Fiebers" recognized by the Russian Symbolists as their own literary technique (Tsivian 1991: 127-128) could be traced in Gogol's and Dostoevsky's work irrespectively of any cinematic experience. Likewise, "the Anglo-Saxon novel with its achronological constructions and variations in time and space", indebted, in Mitry's opinion, to Griffith (Mitry 2000: 98), has had such precursors as Sterne and Romantic writers. There is a permanent dialogue and exchange between visual and verbal practices. Cinematographic "Aesthetik des Fiebers" accepted by the Symbolists as a reflection of an idea of illusory and distorted material existence has been re-valued by younger modernist writers as a fantastic aspect of empirical reality, expression of its mobility and elusiveness. Technical limitations of the early cinema (trembling, flashing, twinkling) were endowed with aesthetic meanings (Tsivian 1991: 126). In the cinema of the 1910s, unclear focus was exploited as a sign of either a sad emotion or vision of a drunk or a short-sighted person who had lost his glasses. Nabokov makes aesthetic experience available for his trite protagonist ("King, Queen, Knave"): thanks to the loss of glasses Franz finds himself in the fantastic colorful world of blurred contours, which is for him a source of uncertainty and anxiety. New spectacles bring back a feeling of comfort and peace. There is a similar episode in A. Remizov's autobiographical cycle "Through the Cut Eyes" written in the 193040s: the short-sighted boy quits the fantastic sound- and colorful world and finds himself in the dull, mathematical reality of well-defined, colorless objects after the doctor prescribes him glasses (Remizov 2000: 61-63). In the whole these developments may be seen as reverberations of the reversed romantic topic of "magic glasses".

It is clear from the aforementioned examples that modernist visuality is not so much a revolution but rather a re-grouping of different cultural elements and their relations, actualization of elements already present in culture. According to Hugo Münsterberg, cinema is an objectification of processes of our consciousness (attention, memory function, anticipation, imagination) (Münsterberg 1970 (1916): 24). Therefore, as it seems, it would be more productive, instead of comparing literature and the cinema in terms of the privileged metalanguage (either literary or cinematographic), to focus on the cognitive functions of both media. Movement and frame are, according to many theorists, two main cinematic invariables. They correspond to the narrative, i.e. a chain of events, and frame (see Ronen 1986) in the work of fiction. In what follows we shall try to define the variable 
function of the observer in relation to these two invariables in modernist film and fiction.

The mirror double: identity vs. difference. The screen world of the cinema is perceived as "another" reality, the world of doubles. Threedimensionality of the film space is deceitful. "Nevertheless, we are never deceived; we are fully conscious of the depth and yet we do not take it for real depth"; "we have reality with all its true dimensions; and yet it keeps the fleeting, passing surface suggestion without true depth and fullness, as different from a mere picture as from a mere stage performance" (Münsterberg 1970 (1916): 23). The same conflict of perception is typical of mirror images, which are actually seen at the plate surface but perceived as being at a distance behind the glass. "In fact, the mirror image is the antithesis of reality, because it too seems to occur within a world "on the other side". And it seems this way because it does not reflect reality but a "duplicate" of reality" (Mitry 2000: 79). On the one hand, the illusory spatial depth of the cinema is analogous to the illusory depth of consciousness in the modernist literature. On the other hand, the literary romantic theme of the double who is both the "I" and the "Other" is optically renewed in the early cinema, e.g. in Méliès' trick films with doubles. However, elaboration of the "double" and "another reality" topic in both the cinema and the fantastic-realist and science fiction of the 1920-30s is built not upon the mystical connotations as in Romanticism but rather upon the properties of space and the dialectics of incomplete identity and self-identification with the mirror image. The protagonist witnesses the double, whose story unfolds in the "parallel" space. Thus, in Bulgakov's "Diavoliada", space with its multiple identical and communicating cells, duplicating surfaces, mirrors, elevators, which, like magic boxes, are capable miraculously change their content, is a double-generating medium. However, identity of the doubles is incomplete, reverse or false: Korotkov-Kolobkov (referring to "Korobkov", i.e. to match-boxes), Kalsoner the bearded vs. Kalsoner the shaved. Likewise, Nabokov's mirror texts ("The Eye", "Despair") are built upon partial or false identity of the doubles. An encounter with a cinematographic unrecognizable double is leitmotival in Nabokov's prose. Ganin can hardly recognize his "sold" shadow on the screen ("Mary"). Magda is unable to make out whether it is her or her mother's image while looking at her caricature filmic performance ("Camera Obcura"). The child on the screen turns away from his 
father: the real child is already dead by the time and the film is shown to compensate for his absence ("Bend Sinister").

Movement: the natural vs. the artificial, animate vs. inanimate. E. Panofsky and other art theorists believe that pleasure of motion lies at the core of cine-psychology. S. Kracauer argues that cinematic movement is a powerful physiological stimulator for the spectator (Kracauer 1974: 217). The protagonist of Nabokov's "Laughter in the Dark" ("Kamera obskura") dreams of bringing a well-known painting to life on the screen. French theorist Elie Faure voiced a similar view on the cinema as animated painting (Iampolsky 1993: 62-63). Portraits and statues coming to life as well as moving automatons, somnambulists and the dead are thematizations of cinema as "moving pictures" and also optical actualizations of certain romantic and neoromantic literary cliches. The FEKS studio experimentation with automatic movement is well known. One of the fathers of cinema Georges Méliès was a professional conjuror and a creator of automatons. In France, Léger and Murphy set animate as well as inanimate objects to clockwork motion in their "Ballet mécanique" (1924). Such films as "Golem", "Homunculus", "The Cabinet of Dr. Caligari" or such works of fiction as "Carpenters", "Shields (and Candles)", "The Fifth Wanderer" by Kaverin or "King, Queen, Knave" by Nabokov render an ability of artificial objects to function as the animated ones or vice versa and involve analysis of the automatic motion.

Photogenics: statics vs. dynamics. The problem of movement is closely connected with photogenics. There was an obsessive idea of the static photogenic beauty in the early cinema. Greta Garbo's face became an object of worship. In the 1920s, a new understanding of "photogenics" was introduced into cinematic discussions by articles of Louis Delluc and Jean Epstein. Delluc argues that the aim of art is taking life "by surprise", a "theft", a snapshot, not a description of a model, a pose, i.e. petrified life of a wax figure. Not a "beauty" is interesting, but expression and individuality (Kino 1988: 80-88). The protagonist of Henry James' short story "The Real Thing" is faced with similar problems. An irreproachably elegant and distinguished woman, a "real thing" with "positive stamp", suggests her sitting for his story-books illustrations and sketches to earn money. But the artist feels she would better suit for advertising purposes of "a waistcoatmaker, a hotel-keeper or a soap-vendor" (James 1976: 111). She has often been photographed because of her capacity to be always the 
same, which is exactly the reason of her uselessness for sketches: she "was capable of remaining for an hour almost as motionless as if she were before a photographer's lens. /.../ I began to find her too insurmontably stiff; do what I would with it my drawing looked like a photograph or a copy of a photograph" (James 1976: 119-120). By comparison with photographic fixation of the unchanging "essences", it is a unique and elusive movement that matters in art. Likewise, art is always a sleight-of-hand, a metamorphosis, an artistic "theft" for Nabokov. Any attempt to fix life results in a dead body ("Kamera obskura", "Despair", "Lolita", etc.). The elusive or metamorphosed object and the alternating point of view are the basic mechanisms of self-reflection in modernist art.

Poetics of the contrast: "saturation" of the frame. A number of critics develops the idea of the "primitive Manicheanism" (Mitry) and the mythological character of the early cinema. The contrast of black and white is thematized in the genres of melodrama and thriller as the conflict of good and evil. Blossom of aesthetics of mystery was stimulated by the colour range of early cinema. In "The Defense" by Nabokov, these contrasts form a dense network of meanings which controls interpretive strategies: black and white (chess, cinema), good and evil (freemasonry, detective and mystery fiction). The early cinema was called "the battle of black and white" (Abel Gance's article "Le temps de l'image est venu!" translated in: Kino 1988: 65). Jacques-Bernard Brunius founded the League of black-and-white in Paris in 1927 to defend the black-and-white cinema (Kino 1988: 290).

Defamiliarization: the close-up as internal movement or deformation. The structural parallel to the close-up is "defamiliarization", or a description of unusual perception of ordinary objects and phenomena as new and strange. Tolstoy's or Montesquieu's "estranged" descriptions of stage performance as seen by children or foreigners are examples of such perceptual shift: the naïve spectator pays attention to minor and second-order details irrelevant for theatrical poetics. However, in the Formalist theory, "the device of making strange" signifies also a new constructive principle which stimulates a new mode of perception: either a new visual technique or a new trope, new type of composition, new generic principle in literature, e.g. the Sternian novel as defamiliarization and "baring of the device" in relation to the traditional novel (Hansen-Löve 2000: 245-250). The cinematic device of close-up evokes both an illusion of observer's movement and an 
effect of alienation. For the unprepared or conservative spectator of early cinema, the close-up was a monstrous distortion, which turned human figures into the aliens (see Tsivian 1991: 161-163). The French theorists of the "new sensitivity" paid special attention to the magnification of a detail as a means to intensify its expression and to emphasize its significance (Kino 1988: 204). It is interesting that in the early cinema the close-up was often motivated by the optical magnification, as in G. A. Smith's films: "In At Last, That Awful Tooth, he justifies the close-up of a decayed tooth by first showing the patient scrutinizing his tooth through a magnifying glass. This technique was to be copied in many other films, such as Grandma's Reading-Glass, What We See through a Telescope, etc." (Mitry 2000: 92). Owing to strong visual component in the early $20^{\text {th }}$ century culture, the visual shift may serve as a metaphor for certain literary techniques. A "strange" or "shifted" detail plays the role of the "dominant" which transfigures the whole combination or the whole field of perception (Gestalt).

\section{References}

Appel, Alfred, Jr. 1974. Nabokov's Dark Cinema. New York: Oxford University Press.

Bakhtin 1979 = Бахтин, Михаил. Эстетика словесного творчества. Москва: Искусство.

- 1994. Проблемы творчества поэтики Достоевского. Киев: NEXT.

Bal, Mieke 1991.On Story-Telling. Essays in Narratology. California: Sonoma.

Bluestone, George 1971. Novels into Film. Berkeley: University of California Press.

Branigan, Edward 1984. Point of View in the Cinema. A Theory of Narration and Subjectivity in Classical Film. Approaches to Semiotics, 66. Berlin-New York-Amsterdam: Mouton Publishers.

Chatman, Seymour 1990. Coming to Terms: The Rhetoric of Narrative in Fiction and Film. Ithaca: Cornell University Press.

Cohn, Dorrit 1995. Optics and power in the novel. New Literary History 26: 3-20.

Crary, Jonathan 1992. Techniques of the Observer: On Vision and Modernity in the 19th Century. Cambridge: MIT Press.

Danesi, Marcel 1995. The iconicity of metaphor. Syntactic Iconicity and Linguistic Freezes. The Human Dimension. Ed. by Marge E. Landsberg. Studies in Anthropological Linguistics, 9. Berlin-New York: Mouton de Gruyter

Derrida, Jacques 1986. Margins of Philosophy. Chicago: The University of Chicago Press.

- 1997. Of Grammatology. Baltimore: The Johns Hopkins University Press. 
Eikhenbaum 1986 = Эйхенбаум, Борис. $O$ прозе. $O$ поэзии. Ленинград: Художественная литература.

Fludernik, Monika 1998 [1993]. The Fictions of Language and the Languages of Fiction. London: Routledge.

Fontanille, Jacques 1989. Les espaces subjectifs. Introduction à la sémiotique de l'observateur (discours - peinture - cinema). Paris: Hachette.

Genette, Gérard 1980 [1972]. Narrative Discourse. Cornell: Cornell University Press.

Gibson, James Jerome 1950. The Perception of the Visual World. Boston: Houghton Mifflin.

Greimas, Algirdas Julien; Courtés, Joseph 1982 [1979]. Semiotics and Language: An Analytical Dictionary. Bloomington: Indiana University Press.

Grishakova, Marina 2001. Metaphor and narrative. Sign Systems Studies 29(2): 503-517.

Hansen-Löve 2000 = Хансен-Леве, Аге. Русский формализм: Методологическая реконструкиия развития на основе остранения. Москва: Языки русской культуры.

Heath, Stephen 1981. Questions of Cinema. Bloomington: Indiana University Press.

Hrushovski, Benjamin 1984. Poetic metaphor and frames of reference. Poetics Today 5(1): 5-44.

Iampolsky 1993 = Ямпольский, Михаил. Видимый мир: Очерки по ранней кинофеноменологии. Москва: Научно-исследовательский институт киноискусства.

Ivanov 1988 = Иванов, Вячеслав. Монтаж как принцип построения в культуре первой половины 20 века. In: Монтаж. Литература. Искусство. Театр. Кино. Москва: Наука, 119-148.

Jahn, Manfred 1996. Windows of focalization: deconstructing and reconstructing a narratological concept. Style, vol. 30, No. 2, pp. 241-267

Jakobson, Roman 1985. Einstein and the science of language. In: Jakobson, Roman, Selected Writings, vol. 7. The Hague: Mouton Publishers, pp. 254264

James, Henry 1976. The Aspern Papers and Other Stories. London: Penguin Books.

James, William 1950. The Principles of Psychology. Vol. 2. New York: Dover Publications.

Jay, Martin 1993. Downcast Eyes: The Denigration of Vision in Twentieth-Century French Thought. Berkeley:University of California Press

Kermode, Frank 1980. Secrets and Narrative Sequence. Critical Inquiry 7(1): 83101

Kino 1988 = Ямпольский, Михаил (ред), Из истории франиузской киномыслл: Немое кино, 1911-1933. Москва: Искусство.

Kracauer 1974 = Кракауэр, Зигфрид. Природа фильма. Москва: Искусство

Lacan, Jacques 1994. The Four Fundamental Concepts of Psychoanalysis. London: Penguin Books.

Lakoff, George and Johnson, Mark 1981. Metaphors We Live By. Chicago and London: The University of Chicago Press 
Langacker, Ronald W. 2000. Grammar and Conceptualization. Berlin: Mouton de Gryter.

Lotman 1981 = Лотман, Юрий. Риторика. Sign Systems Studies (Tpydbl no знаковыи системам) 12: 8-28.

Lyons, John 1977. Semantics, vol. 2. Cambridge: Cambridge University Press.

McQuire, Scott 1998. Visions of Modernity. Representation, Memory, Time and Space in the Age of Camera. London: SAGE Publications.

Merleau-Ponty, Maurice 1981 [1945]. Phenomenology of Perception. London: Routledge \& Kegan Paul.

- 1987 [1968]. The Visible and the Invisible. Evanston: Nothwestern University Press

Metz, Christian 1991. Film Language: A Semiotics of the Cinema. Chicago: The University of Chicago Press.

Mitry, Jean 2000 [1963]. The Aesthetics and Psychology of the Cinema. (Transl. by Christopher King.) Bloomington: Indiana University Press.

Michalski, Milena 2000. Cinematic literature and literary cinema: Olesha, Room and the search for a new art form. In: Kelly, C.; Lovell, S. (eds.), Russian Literature, Modernism and the Visual Arts. Cambridge, UK - New York: Cambridge University Press.

Moses, Gavriel 1995. The Nickel Was for the Movies: Film in the Novel from Pirandello to Puig. Berkeley : University of California Press.

Mukaŕovsky 1994 = Мукаржовский, Ян. Исследования по эстетике и теории искусства. Москва: Искусство.

Münsterberg, Hugo 1970 [1916]. The Film: A Psychological Study. New York: Dover Publications.

Nabokov, Vladimir 1997. The Collected Stories. London: Penguin.

Nünning, Angsar 2001. On the Perspective Structure of Narrative Texts: Steps toward a Constructivist Narratology. New Perspectives on Narrative Perspective. Ed. by W. van Peer and S. Chatman. Albany: State University of New York Press, pp. 207-224.

Phelan, James 2001. Why Narrators Can Be Focalizers - and Why It Matters. New Perspectives on Narrative Perspective. Ed. by W. van Peer and S. Chatman. Albany: State University of New York Press, pp.51-66.

Proust, Marcel 1954. Du côté de chez Swann. Paris: Gallimard.

Remizov 2000 = Ремизов, Алексей. Собрание сочинений. Том 8. Москва: Русская книга.

Ricoeur, Paul 1990. Time and Narrative. Vol. 1-3. Chicago: The University of Chicago Press.

Rimmon-Kenan, Shlomith 1983. Narrative Fiction: Contemporary Poetics. London: Methuen.

Ronen, Ruth 1986. Space in fiction. Poetics Today 7(3): 421-438.

Sanders, José; Gisela Redeker 1996. Perspective and the representation of speech and thought in narrative discourse. In: Fauconnier, G.; Sweetser, Eve (eds.), Spaces, Worlds, and Grammar. Chicago: The University of Chicago Press, 290-317.

Shattuck, Roger 1964. Proust's Binoculars. A Study of Memory, Time, and Recognition in "A la recherche du temps perdu". London: Chatto \& Windus. 
Stern, Josef 2000. Metaphor in Context. Cambridge: The MIT Press.

Timenchik 1989 = Тименчик, Роман. К вопросу о монтажных построениях в поэтическом тексте. Sign Systems Studies (Tруды по знаковым системам) 23: $145-150$.

Tsivian 1991 = Цивьян, Юрий. Историческая рецепщия кино. Кинематограф России 1896-1930. Рига: Зинатне.

Uexküll, Thure von 1984. Semiotics and the problem of the observer. Semiotica 48 (3/4): 187-196.

Uspensky $1970=$ Успенский, Борис. Поэтика композищии. Москва: Искусство.

Vinogradov 1980 = Виноградов, Виктор. О языке художественной прозы . Москва: Наука.

Vitz, Paul C.; Glimcher, Arnold B. 1984. Modern Art and Modern Science: The Parallel Analysis of Vision. New York: Praeger Publishers.

\section{К семиотике наблюдателя}

Проблема наблюдателя и точки зрения рассматривается в широкой семиологической и когнитивной перспективе. Структуралистская нарратология пыталась построить формально-лингвистическую классификацию точек зрения и таким образом избежать антропоморфно-визуальных коннотаций, присутствуюших в нарратологических терминах, которые по своему происхождению являются метафорами. Другая возможность - использование терминов-метафор как теоретических моделей, с извлечением всех возможных эвристических последствий. С точки зрения наблюдателя, процесс текстопорождения происходит в двойном измерении перцепции/ концерции и интерпретации. На этой когнитивной основе возможны более широкие и продуктивные интермедиальные сравнения.

\section{Vaatleja semiootikast}

Vaatleja ja vaatepunkti probleemi vaadeldakse laias semioloogilises ja kognitiivses perspektiivis. Strukturalistlik narratoloogia püüdis luua formaal-lingvistilist vaatepunktide klassifikatsiooni, vältimaks visuaalantropomorfseid konnotatsioone, mis kaasnevad narratoloogiliste terminitega, mis oma päritolult on metafoorid. Teine võimalus on termin-metafooride kui teoreetiliste mudelite kasutamine, koos kõigi võimalike heuristiliste tagajärgedega. Vaatleja vaatepunktist toimub tekstiloomeprotsess kahes mõõtmes - pertseptsioon/kontseptsioon ja interpretatsioon. Sellel kognitiivsel alusel on võimalikud laiemad ja produktiivsemad intermediaalsed võrdlused. 